will do so if we admit their inherent ambiguity, viewing them somewhat in the manner that we have learned to view love-as something our inability to describe does not tarnish." Besides indicating the sort of contribution this work makes to the literature of contemporary political theory, these words testify to the spirit of a man whose temperament, mirroring his intellectual convictions, was democratic to the core.

A long-standing member of the American Political Science Association, Bob was also an active participant in the American Academy of Political and Social Science, the American Association of University Professors, and the Western Political Science Association. Moreover, he served as vice president from 1958-59 and president from 1970-71 of the Pacific Northwest Political Science Association.

Bob married artist and poet Ruth Fluno on January 18, 1944. She died November 24, 1974. He was remarried to Marcella Kerins on February 17, 1979 in Walla Walla. Survivors include Marcella; his sister, Helen Jean Rodrigues-Torrent of Clearwater, Florida; a brother, John Fluno of Winter Park; three nieces; and one nephew.

Memorial contributions may be made to the Robert Y. Fluno Award Endowment at Whitman College.

Graeme Auton

Redlands University

Timothy V. Kaufman-Osborn

Whitman College

\section{John H. E. Fried}

John H. E. Fried, a member of the American Political Science Association for some 50 years, died on December 18 , at the age of 85 , after a brief illness.

Born and educated in Vienna, John had a distinguished career as a teacher and practitioner of international law and as an activist in the cause of peace and world order. At the end of World War II he served as special counsel to the United States War Crimes Tribunal, following which he edited the 14-volume record of the 12 trials. John worked in various capacities for the United Nations and was selected as an ar- bitrator in a number of international disputes. He taught international law at the graduate center of the City University of New York and at Lehman College, where he was professor emeritus of political science at the time of his death.

An indefatigable lecturer and writer, John made numerous contributions to the literature of international law. His early association with Nuremberg and the other war crimes trials helped to focus and define his interests for the balance of his life. John's commitment to the theories of crimes against the peace, war crimes and crimes against humanity were the underpinnings of his active opposition to the Vietnam war and the use and threat of use of nuclear weapons. As one of the last survivors of the band of "Nuremberg jurists," John felt a special responsibility to keep the Nuremberg idea alive. But he made many other important contributions to the thinking of his colleagues, including his advocacy of the right to peace as a crucial, "third generation" human right. He was honored at a testimonial party in December 1989 by the Lawyers' Committee on Nuclear Policy and by then Manhattan Borough President David N. Dinkins, who declared December 14 as "John H. E. Fried and the Right to Peace Day" in Manhattan.

John gave unstintingly, not only of his ideas, but also of his time, his interest, and his encouragement to students and colleagues alike. If more international lawyers acted as courageously as John did on the principles they espouse, and if more peace activists took international law as seriously, the world would be a better place.

Peter Weiss

Lawyers' Committee on

Nuclear Policy

\section{Victor Adeola Olorunsola}

On September 29, 1990, the profession lost a noted African scholar. Victor A. Olorunsola died after a long battle with cancer.

Born in Nigeria, Victor completed his undergraduate studies at Friends University with high honors. After completing his master's and doctoral degrees at Indiana University, he taught in the department of political science at California State University, Long Beach, before moving to Iowa State University. During his 20 years at Iowa State, Victor gained an international reputation for his expertise on African politics and on the politics of ethnicity. His major works included The Politics of Cultural Sub-Nationalism in Africa (1972), Societal Reconstruction in Two African States (1977), Soldiers and Power (1977), and State Versus Ethnic Claims: An African Policy Dilemma (1983). He was awarded numerous grants from the Social Science Research Council, the Ford Foundation, the Hoover Institution, the Rockefeller Foundation, and the Rothchild Foundation. In 1981, he organized the Rockefeller Bellagio Conference on State Coherence and Ethnicity.

Victor also developed a reputation as a devoted teacher and a supportive colleague. As chairperson of the department of political science for ten years, Victor built the Ph.D. program. He chaired the University's Departmental Executive Officers Council, coordinated Graduate Studies, and served on a wide range of committees including the Presidential Search Committee, the University Performing Arts Council, the University Committee on the World Food Institute, the College Committee on International Programs, the Truman Fellowship Committee, and the ISU-USAID Zambia Project Advisory Committee. At the national level, Victor served as a member of the Executive Council of the American Political Science Association and as a member of the Board of Directors and the Executive Committee of the African Studies Association. He served for many years as an evaluator of proposals and fellowship applications for the National Science Foundation.

In 1987, Victor became Dean of the College of Arts and Sciences at the University of Louisville. During his administration he restructured the Arts and Sciences Advising Center, introduced an orientation course to facilitate the matriculation of Arts and Sciences undergraduate students, enhanced the college honors program, funded lecture series in 